\title{
Casein Kinase II Phosphorylates the Synaptic Vesicle Protein p65
}

\author{
Mark K. Bennett, Kenneth G. Miller, and Richard H. Scheller \\ Howard Hughes Medical Institute, Department of Molecular and Cellular Physiology, Beckman Center for Molecular and \\ Genetic Medicine, Stanford University Medical Center, Stanford, California 94305
}

\begin{abstract}
p65 (synaptotagmin), an abundant synaptic vesicle protein, has been implicated in the processes of vesicle docking and fusion. To characterize further the properties of this important neuronal protein, we have investigated its phosphorylation in vitro. Immunoprecipitation of p65 results in coprecipitation of a protein kinase that phosphorylates p65 as well as syntaxin, a plasma membrane protein that interacts with p65. p65 is phosphorylated on a threonine residue (Thr-128) within the cytoplasmic domain near the transmembrane region. The coprecipitating protein kinase was identified as casein kinase II based on its catalytic properties, the sequence surrounding Thr-128, and Western blot analysis of the anti-p65 immunoprecipitates. Affinity chromatography utilizing bacterially expressed fragments of p65 demonstrated that casein kinase II interacts with a domain of p65 distinct from the phosphorylation site. In a synaptic vesicle fraction, the phosphorylation of p65 is stimulated by sphingosine and by detergent solubilization, suggesting that p65 phosphorylation may be subject to regulatory processes.

[Key words: synaptic vesicles, p65, casein kinase II, syntaxin, exocytosis, sphingosine]
\end{abstract}

Synaptic transmission, the principal means of intercellular communication within the nervous system, is mediated by the cxocytotic release of chemical neurotransmitter. One of the central elements in this process are the synaptic vesicles responsible for the storage and stimulation-dependent release of neurotransmitter. Within the nerve terminal, synaptic vesicles undergo repeated cycles of regulated fusion and recycling (for reviews, see Kelly, 1988; Südhof and Jahn, 1991; Trimble et al., 1991). In the resting terminal, synaptic vesicles are clustered near the presynaptic active zone, often in association with cytoskeletal elements. Upon nerve stimulation, calcium influx triggers the fusion of synaptic vesicles with the presynaptic plasma membrane, resulting in the release of neurotransmitter into the synaptic cleft. After exocytosis, the components of the synaptic vesicle membrane are selectively recovered by endocytosis and locally recycled into mature synaptic vesicles. A molecular de-

\footnotetext{
Received Aug. 3, 1992; revised Oct. 16, 1992; accepted Oct. 20, 1992.

We thank Howard Schulman and Jonathan Pevsner for helpful discussions and critical reading of the manuscript. We thank Louis Reichardt and Michael Dahmus for generous provision of antibodies, Howard Schulman for providing cAMPdependent and type II Ca${ }^{2+} /$ calmodulin-dependent protein kinases, Daria MochlyRosen for providing protein kinase $C$, and Phyllis Hanson for assistance in phosphoamino acid analysis. This work was supported by the National Institute of Mental Health.

Correspondence should be addressed to Richard H. Scheller at the above address.

Copyright (C) 1993 Society for Neuroscience $0270-6474 / 93 / 131701-07 \$ 05.00 / 0$
}

scription of synaptic vesicle membrane traffic, including its physiological regulation, is required for a more complete understanding of synaptic transmission.

One mechanism by which synaptic vesicle function, and in turn synaptic transmission, might be physiologically regulated is by protein phosphorylation. This has been well established for the peripheral synaptic vesicle protein synapsin I (DeCamilli and Greengard, 1986; Südhof et al., 1989). Phosphorylation of synapsin I by $\mathrm{Ca}^{2+} /$ calmodulin-dependent protein kinase II regulates its interaction with both synaptic vesicles and actin filaments (Schiebler et al., 1986; Benfenati et al., 1992). This in turn may regulate the availability of synaptic vesicles for release (Llinás et al., 1985). A number of additional synaptic vesicle membrane proteins have been isolated and/or their cDNAs cloned (Trimble and Scheller, 1988; Südhof and Jahn, 1991). One of these proteins is p65 (synaptotagmin), a transmembrane protein with two repeats in the cytoplasmic domain homologous to the $\mathrm{C} 2$ regulatory domain of protein kinase $\mathrm{C}$ (Matthew et al., 1981; Perin et al., 1990; Wendland et al., 1991). The C2 regulatory domain is required for interaction of phosphatidylinositol bisphosphate with protein kinase $\mathrm{C}$ (Huang and Huang, 1991; Lee and Bell, 1991) and the stimulation-dependent translocation of phospholipase $A_{2}$ from a soluble to a membraneassociated form (Clark et al., 1991). It has been proposed that the C2-homologous domains of p65 may be involved in the interaction of synaptic vesicles with the plasma membrane (Perin et al., 1990; Südhof and Jahn, 1991). Recent studies support a role for $\mathrm{p} 65$ in the processes of synaptic vesicle docking and/ or fusion (Petrenko et al., 1991; Bennett et al., 1992b; Brose et al., 1992).

Because of the proposed central role of $\mathrm{p} 65$ in synaptic vesicle function and the possibility that this function might be the target of physiological regulation, we have investigated the in vitro phosphorylation of p65. We have found that casein kinase II, a ubiquitous cellular protein kinase, both interacts with and phosphorylates p65.

\section{Materials and Methods}

Materials. Electrophoresis-grade reagents, gelatin, and Triton X-100 were purchased from Bio-Rad Laboratories (Richmond, CA). CHAPS and octylglucoside were obtained from Boehringer Mannheim Biochemicals (Indianapolis, IN). Bovine serum albumin, glutathione-agarose, thrombin, TPCK-treated trypsin, and reagent-grade chemicals were oblained from Sigma Chemical Co. (St. Louis, MO). ${ }^{125}$ I-labeled and peroxidase-conjugated anti-mouse IgG were obtained from ICN (Irvine, CA) and Zymed (San Francisco, CA), respectively. Prestained SDSPAGE molecular weight standards were purchased from Bethesda Research Laboratories (Gaithersburg, MD) and protein A-sepharose was obtained from Pharmacia LKB Biotechnology (Piscataway, NJ). $\gamma-{ }^{32} \mathrm{P}$ ATP was from DuPont/New England Nuclear (Boston, MA). Monoclonal antibody M48 (anti-p65; Matthew et al., 1981) was provided by 
Dr. Louis Reichardt (University of California at San Francisco). Affinity-purified ascites fluid of anti-p65 $(1.5 \mathrm{mg} / \mathrm{ml})$ was prepared by Berkeley Antibody Co. (Richmond, CA). A rabbit polyclonal antibody generated against casein kinase II (Dahmus et al., 1984) was kindly provided by Dr. Michael Dahmus (University of California at Davis). Synthetic peptides were prepared by the Protein and Nucleic Acid Facility, Beckman Center, Stanford University.

p65 immunoprecipitation. A synaptic vesicle-enriched fraction (LP2) from rat brain was prepared by a modification of the procedure of Huttner et al. (1983), as previously described (Bennett et al., 1992a). Protein concentrations were determined by the BCA assay (Pierce, Rockford, IL; Smith et al., 1985) with bovine serum albumin as a standard. Immunoprecipitations with anti-p65 monoclonal antibody M48 were performed on LP2 $(1.5 \mathrm{mg} / \mathrm{ml})$ solubilized in HKA buffer

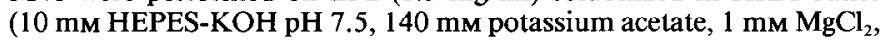
$0.1 \mathrm{~mm}$ EGTA, $0.1 \%$ gelatin, $0.1 \%$ bovine serum albumin) containing either $2 \%$ CHAPS, $2 \%$ Triton X-100, or $4 \%$ octylglucoside. Anti-p65 was prebound to protein A-Sepharose beads (1-3 $\mu \mathrm{l}$ antibody/ $\mu \mathrm{l}$ beads) for $2 \mathrm{hr}$ prior to addition to the solubilized LP2 preparations $(10-20 \mu \mathrm{l}$ beads/mg LP2 protein). After incubation for $2-4 \mathrm{hr}$ at $4^{\circ} \mathrm{C}$, the beads were recovered by brief centrifugation in a microfuge and washed three times with HKA buffer (containing either 1\% CHAPS, Triton X-100, or octylglucoside), and bound proteins were eluted with SDS-PAGE sample buffer or assayed for in vitro phosphorylation as described below.

In vitro phosphorylation assays. Anti-p65 immunoprecipitates from detergent-solubilized LP2 $(0.5 \mathrm{mg}$ of protein) were prepared as described above. The immune complexes were resuspended in $90 \mu \mathrm{l}$ of reaction buffer (50 mM Tris pH 7.5, $10 \mathrm{mM} \mathrm{MgCl}_{2}, 0.7 \mathrm{mM} \mathrm{CaCl}_{2}, 0.4 \mathrm{~mm}$ EGTA) containing $1 \%$ CHAPS and preincubated at $30^{\circ} \mathrm{C}$ for $1 \mathrm{~min}$. Exogenous bacterially expressed p65 fragments $(20 \mu \mathrm{g} / \mathrm{ml})$ or synthetic peptides $(0.5 \mathrm{~mm})$ were included in the reaction mixture as indicated. The phosphorylation reaction was initiated by addition of $10 \mu \mathrm{l}$ of $\gamma^{32} \mathrm{P}-$ ATP $(0.2 \mathrm{~mm}, 50 \mu \mathrm{Ci} / \mathrm{ml})$. Following incubation for $5 \mathrm{~min}$ at $30^{\circ} \mathrm{C}$, the reaction was terminated by addition of $400 \mu$ lof ice-cold HKA buffer containing $1 \%$ CHAPS, $20 \mathrm{~mm}$ EDTA, $1 \mathrm{~mm}$ EGTA. The immune complexes were recovered by brief centrifugation in a microfuge and eluted with SDS-PAGE sample buffer. Proteins remaining in the supernatant fractions were recovered by trichloroacetic acid precipitation and solubilized in SDS-PAGE sample buffer. Following SDS-PAGE, the total protein patterns were determined by Coomassie bluc staining, and the pattern of protein phosphorylation was detected by autoradiography. For quantitation of $\mathrm{p} 65$ phosphorylation, the region of the gel containing p65 was excised and radioactivity was quantitated by Cerenkov counting ( $61 \%$ counting efficiency). The total amount of p65 present in the immunoprecipitates was estimated from the Coomassie blue-stained gel by comparison with known amounts of bovine serum albumin. Quantitation of synthetic peptide phosphorylation was performed as described by Racker and Sen (1991).

Phosphorylation of crude LP2 $(500 \mu \mathrm{g})$ was carried out as described above in a reaction volume of $500 \mu \mathrm{l}$. Exogenous lipids (dissolved at $10 \mathrm{mg} / \mathrm{ml}$ in dimethyl sulfoxide) and detergent were added as indicated. The reactions were terminated by addition of $500 \mu$ ice-cold stop buffer ( $50 \mathrm{~mm}$ Tris pH 7.5, $40 \mathrm{~mm}$ EDTA, $4 \mathrm{~mm}$ EGTA, 4\% octylglucoside). Ten percent of each sample was subjected to precipitation with trichloroacetic acid, and the remainder was subjected to immunoprecipitation with anti-p65 prior to analysis by SDS-PAGE and autoradiography.

Tryptic phosphopeptide mapping. In vitro phosphorylated $\mathrm{p} 65$ and fragment 123 were resolved by SDS-PAGE, localized by autoradiography, and excised. The gel slices were washed sequentially for $1 \mathrm{hr}$ with each of the following: (1) $20 \%$ isopropanol, $10 \%$ acetic acid; (2) $20 \%$ isopropanol; and (3) $10 \%$ methanol. The gel slices were dried under vacuum, swollen in $100 \mu \mathrm{l}$ of $50 \mathrm{mM} \mathrm{NH}_{4} \mathrm{HCO}_{3}$ (pH 7.9) containing 50 $\mu \mathrm{g}$ of TPCK-treated trypsin, and incubated at $37^{\circ} \mathrm{C}$ for $4 \mathrm{hr}$. One milliliter of $50 \mathrm{mM} \mathrm{NH}_{4} \mathrm{HCO}_{3}(\mathrm{pH} 7.9)$ containing $50 \mu \mathrm{g}$ of TPCK-treated trypsin was added and the incubation continued for an additional 12 $\mathrm{hr}$ at $37^{\circ} \mathrm{C}$. The gel slice eluates were lyophilized, suspended in $100 \mu \mathrm{l}$ buffer $\mathrm{A}(0.1 \%$ trifluoroacetic acid), and loaded onto a $\mathrm{C} 18$ reversephase HPLC column equilibrated with $5 \%$ buffer $\mathrm{B}(0.085 \%$ trifluoroacetic acid, $70 \%$ acetonitrile, $30 \% \mathrm{H}_{2} \mathrm{O}$ ). The column was developed at a flow rate of $200 \mu \mathrm{l} / \mathrm{min}$ with the following gradient: $0-5 \mathrm{~min}, 5 \%$ buffer B; $5-50 \mathrm{~min}, 5-55 \%$ buffer B; $50-55 \mathrm{~min}, 55-75 \%$ buffer B; $55-$ $60 \mathrm{~min}, 75-95 \%$ buffer $\mathrm{B}$. Labeled peptides were detected in fractions by Cerenkov counting.

Fusion protein production and purification. Recombinant plasmids encoding glutathione S-transferase (GST) linked by a thrombin-cleavage sequence to fragments of $p 65$ were constructed by cloning polymerase chain reaction products of a rat $\mathrm{p} 65 \mathrm{cDNA}$ into the expression vector pGEX-KG (Guan and Dixon, 1991). The oligonucleotide primers used for polymerase chain reaction included EcoRI and $\mathrm{Ncol}$ restriction sites permitting in-frame directional cloning of the product into EcoRI/NcoIdigested PGEX-KG vector. The recombinant plasmids were transfected into the AB1899 strain of Escherichia coli and fusion protein expression induced with $100 \mu \mathrm{M}$ isopropyl- $\beta$-D-thiogalactopyranoside for $5 \mathrm{hr}$. The cells were harvested, suspended in PBS containing $0.05 \%$ Tween 20,2 mM EDTA, and $0.1 \%$ 2-mercaptoethanol, and lysed by two passages through a French press. Cellular debris was removed by centrifugation at $10,000 \times g$ for $10 \mathrm{~min}$, and the fusion protein was recovered from the supernatant by binding of the GST domain to glutathione-agarose beads equilibrated with PBST (PBS, $0.05 \%$ Tween 20) for $30 \mathrm{~min}$ at $4^{\circ} \mathrm{C}$. The beads were washed four times with PBST and either transferred to storage buffer ( $50 \mathrm{~mm}$ Tris pH 8.0, $150 \mathrm{~mm} \mathrm{NaCl}, 2.5 \mathrm{~mm} \mathrm{CaCl}_{2}$ ) for use in affinity chromatography (see below), or the p65 fragment was recovered by cleavage with thrombin $(3 \mu \mathrm{g} / \mathrm{ml}$ in $50 \mathrm{mM}$ Tris $\mathrm{pH} 8.0$, $150 \mathrm{mM} \mathrm{NaCl}, 2.5 \mathrm{~mm} \mathrm{CaCl}_{2}, 0.1 \% 2$-mercaptoethanol) for $20 \mathrm{~min}$ at room temperature.

p65 affinity chromatography. Quick-frozen rat brains (Bioproducts, Indianapolis, IN), stored at $-70^{\circ} \mathrm{C}$, were immersed for $9 \mathrm{~min}$ in room temperature homogenization buffer $(10 \mathrm{~mm}$ Tris pH $7.5,160 \mathrm{~mm} \mathrm{NaCl}$, $20 \mathrm{mM} \mathrm{CaCl} ; 3 \mathrm{ml} /$ brain) and homogenized in a Teflon/glass homogenizer. The homogenate was subjected to centrifugation first at 10,000 $\times g$ for $15 \mathrm{~min}$ at $2^{\circ} \mathrm{C}$ and then at $100,000 \times g$ for $50 \mathrm{~min}$ at $2^{\circ} \mathrm{C}$. Thc pellet obtained from the second centrifugation (P2) was resuspended in $10 \mathrm{~mm}$ Tris pH 7.5, $160 \mathrm{~mm} \mathrm{NaCl}, 10 \mathrm{~mm} \mathrm{CaCl}_{2}, 1.3 \%$ Triton X-100 at a protein concentration of $2.5 \mathrm{mg} / \mathrm{ml}$ and incubated at room temperature for $10 \mathrm{~min}$ on a rotary shaker. Insoluble material was removed by centrifugation at $100,000 \times g$ for $50 \mathrm{~min}$ at $2^{\circ} \mathrm{C}$. Affinity columns were prepared by adding GST-p65 fusion proteins bound to glutathioneagarose beads $(0.5 \mathrm{ml}$ bed volume) to a $2 \mathrm{ml}$ PolyPrep column (BioRad, Richmond, CA). Solubilized P2 (11 ml) was loaded on the column at a rate of $12 \mathrm{ml} / \mathrm{hr}$, and the column was then washed four times with $2.5 \mathrm{ml}$ of wash buffer ( $10 \mathrm{~mm}$ Tris pH $7.5,160 \mathrm{~mm} \mathrm{NaCl}, 2 \mathrm{mM} \mathrm{CaCl}_{2}$, $0.1 \%$ Tween 20 ) at a flow rate of $36 \mathrm{ml} / \mathrm{hr}$. After the final wash, the beads were resuspended in $150 \mu$ l elution buffer (10 mM Tris, $\mathrm{pH} 7.5$, $250 \mathrm{~mm} \mathrm{NaCl}, 2 \mathrm{~mm} \mathrm{CaCl}_{2}, 10 \mathrm{~mm}$ EGTA) and transferred to a $5 \mathrm{ml}$ snap-cap tubc. An additional $1 \mathrm{ml}$ of elution buffer was used to rinse the column before being added to the bead suspension. The beads were then incubated for $8 \mathrm{~min}$ on a rotary shaker at room temperature. The eluant was collected by gravity filtration over a fresh PolyPrep column and eluted proteins recovered by precipitation with trichloroacetic acid.

SDS-PAGE and Western blotting. SDS-PAGE was performed by the method of Laemmli $(1970)$. The stacking gel $(10 \times 90 \times 1.5 \mathrm{~mm})$ contained $4.8 \%$ acrylamide, $0.2 \%$ bisacrylamide, and the resolving gel $(55 \times 90 \times 1.5 \mathrm{~mm})$ contained $12 \%$ acrylamide, $0.2 \%$ bisacrylamide. Proteins resolved by SDS-PAGE were electrophoretically transferred to nitrocellulose in $384 \mathrm{~mm}$ glycine, $50 \mathrm{~mm}$ Tris base, and $20 \%$ methanol (Towbin et al., 1979). The nitrocellulose filters were incubated with blocking buffer $(10 \mathrm{~mm}$ Tris- $\mathrm{HCl} \mathrm{pH} 7.5,150 \mathrm{~mm} \mathrm{NaCl}, 1 \%$ bovine serum albumin, $0.5 \%$ Tween 20 ) for $30 \mathrm{~min}$ and then transferred to anti-casein kinase II antiserum (1:1000 in blocking buffer) for $2 \mathrm{hr}$. The blots were washed three times for 5 min with blocking buffer and then incubated either with ${ }^{125} \mathrm{I}$-labeled $(1-2 \mu \mathrm{Ci} / \mathrm{ml})$ or peroxidase-conjugated anti-rabbit secondary antibodies for $2 \mathrm{hr}$. The blots were again washed three times for $5 \mathrm{~min}$ each, blotted dry, and exposed to XAR-5 film (125I-secondary) or processed with ECL reagents (Amersham, Arlington Heights, IL; peroxidase-secondary).

\section{Results and Discussion}

\section{Phosphorylation of 065 by a copurifying protein kinase}

To determine if the synaptic vesicle protein 065 is an in vitro protein kinase substrate, a synaptic vesicle-enriched fraction (LP2) from rat brain was solubilized in octylglucoside and subjected to immunoprecipitation with anti-p65 monoclonal antibody. The immunoprecipitate was then subjected to in vitro phosphorylation by addition of $\gamma-{ }^{32} \mathrm{P}-\mathrm{ATP}$ and resolved by SDSPAGE, and phosphoproteins were detected by autoradiography. As shown in Figure 1, p65 was the most prominent phosphorylated protein. Since p65 has no homology to the catalytic do- 


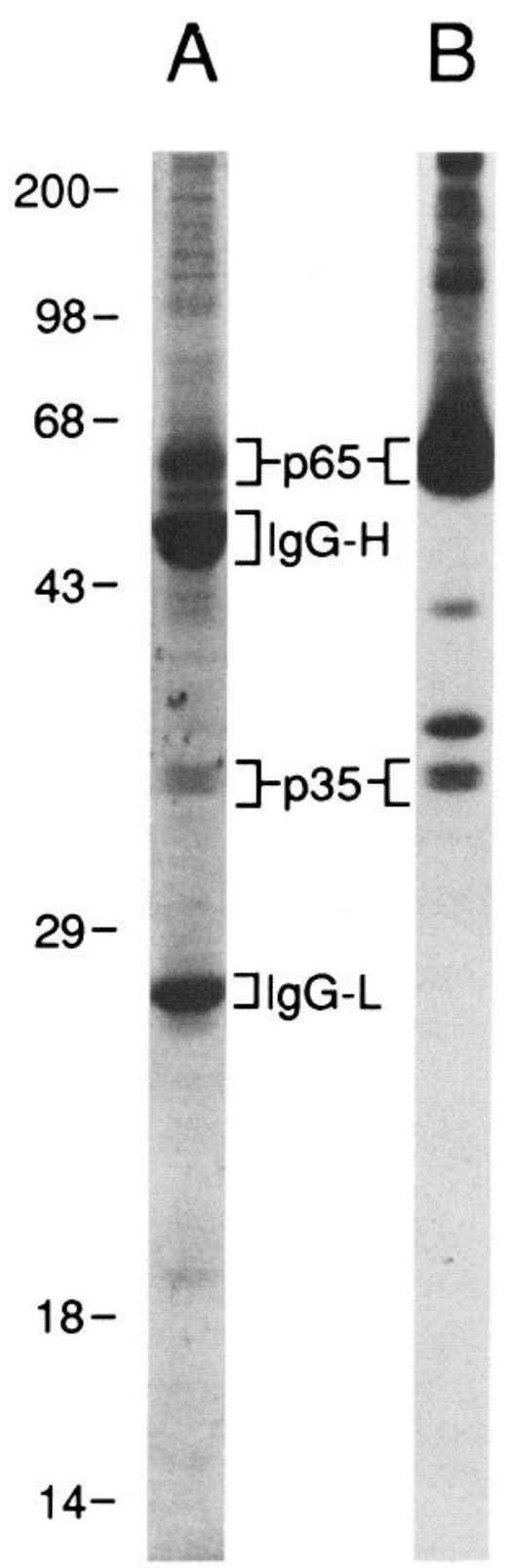

Figure 1. Phosphorylation of $\mathrm{p} 65$ by a copurifying protein kinase. $\mathrm{p} 65$ was isolated by immunoprecipitation from an octylglucoside-solubilized synaptic vesicle-enriched fraction and the immunoprecipitate phosphorylated in vitro as described in Materials and Methods. The phosphorylation reaction was resolved by SDS-PAGE and analyzed by Coomassie blue staining $(A)$ and autoradiography $(B)$. The positions of molecular weight standards, p65, syntaxin (p35), and the heavy (IgG$\mathrm{H})$ and light (IgG-L) chains of anti-p65 are indicated.

mains of protein kinases (Hanks and Quinn, 1991), the observed phosphorylation of p65 must be due to a coprecipitated protein kinase. A protein that interacts with p65, the plasma membraneassociated protein syntaxin (p35; Bennett et al., 1992b), was also phosphorylated. Phosphoamino acid analysis revealed that p65 was phosphorylated on threonine residues. No increase in p65 phosphorylation was detected upon addition of the catalytic subunit of cAMP-dependent protein kinase, protein kinase $\mathrm{C}$ in the presence of calcium and phospholipid, or $\mathrm{Ca}^{2+} /$ calmodulin-dependent protein kinase II in the presence of calcium and calmodulin (data not shown). This suggests that these three
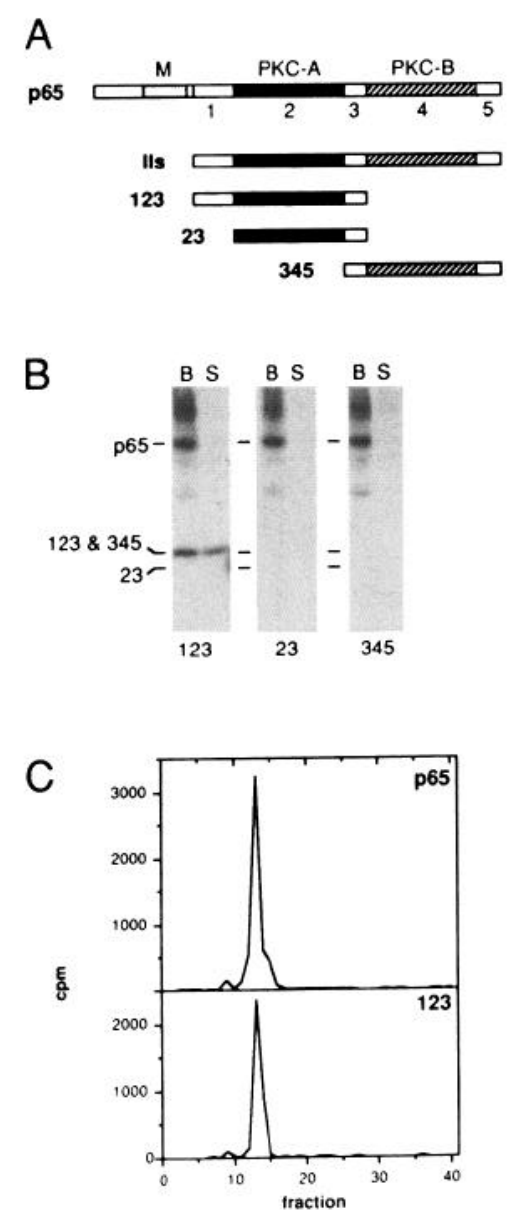

Figure 2. Identification of the domain of $\mathrm{p} 65$ phosphorylated. $A$, Schematic diagram of p65 (top) and fragments of p65 (IIs, 123, 23, and 345) generated by expression in bacteria as GST fusion proteins. The location of the transmembrane domain $(M)$ and the two cytoplasmic repeats homologous to the $\mathrm{C} 2$ regulatory domain of protein kinase $\mathrm{C}$ ( $P K C$ - $A$ and $P K C-B)$ are indicated. $B$, Soluble fragments of p65 $(123,23$, and $345 ; 20 \mu \mathrm{g} / \mathrm{ml}$ ) were added to anti-p65 immunoprecipitates and subjected to in vitro phosphorylation as described in Materials and Methods. The immune complex, retained on the protein A-Sepharose beads $(B)$, and supernatant $(S)$ were separated, resolved by SDS-PAGE, and analyzed by autoradiography. The positions of p 65 and p 65 fragments are indicated. $C$, Phosphopeptides generated by trypsin digestion of p65 and fragment 123 were resolved by reverse-phase HPLC as described in Materials and Methods. Radioactivity recovered in the fractions collected during elution was monitored by Cerenkov counting.

serine/threonine protein kinases are not responsible for the observed phosphorylation of p65. The stoichiometry of p65 phosphorylation by the copurifying protein kinase was maximally 1 mol of phosphate per mole of $\mathrm{p} 65$.

The domain of p65 phosphorylated was determined by evaluating the ability of soluble fragments of p65 to serve as substrates for the coprecipitated kinase. Fragments of the cytoplasmic domain of p65 (Fig. $2 A$ ) were prepared by expression in bacteria as GST fusion proteins and subsequent purification by glutathione-agarose chromatography and thrombin cleavage. The soluble p65 fragments were then added to anti-p65 immunoprecipitates, incubated in the presence of $\gamma-{ }^{32} \mathrm{P}-\mathrm{ATP}$, and analyzed by SDS-PAGE and autoradiography (Fig. $2 B$ ). The fragment of p65 including cytoplasmic domains 1,2 , and $3(123$; amino acids 96-265) was a substrate for the coimmunoprecip- 
Table 1. Identification of the p65 phosphorylation site

\begin{tabular}{llc} 
Substrate & Sequence & $\begin{array}{c}\text { Phosphorylation } \\
\text { rate (pmol/min) }\end{array}$ \\
\hline p65 domain 1 & 96 -GGKNAINMKDVKDLGKTMKDQALKDDDAETGLTDGEEK- 133 & \\
Peptide A & YKDLGKTMKDQALK & 0 \\
Peptide B & YDDDAETGLTDGEEK & 14.1 \\
Peptide C & YDDDAEAGLTDGEEK & 30.5 \\
Peptide D & YDDDAETGLADGEEK & 0.8 \\
\hline
\end{tabular}

Synthetic peptides corresponding to different regions of p65 domain I were added at a concentration of $0.5 \mathrm{~mm}$ to in vitro phosphorylation reactions of anti-p65 immunoprecipitates. Following the reaction, residual $\gamma-{ }^{32} \mathrm{P}-\mathrm{ATP}$ was hydrolyzed by boiling in $1 \mathrm{M} \mathrm{HCl}$ and peptides were separated by extraction in $0.55 \%(\mathrm{w} / \mathrm{v})$ ammonium molybdate, $0.5 \mathrm{M}$ perchloric acid, $22 \%(\mathrm{v} / \mathrm{v})$ isobutanol, $22 \%(\mathrm{v} / \mathrm{v})$ benzenc as described by Racker and Sen (1991). Phosphopeptides recovered in the aqueous phase were quantitated by Cerenkov counting. The tyrosine residue at the amino-terminus of each peptide was included to allow spectrophotometric quantitation of peptide concentrations. Potential phosphorylation sites (threonine residues) are underlined. itated kinase, while fragments including domains 2 and $3(23$; amino acids $130-265)$ or 3 , 4 , and 5 (345; amino acids $248-$ 421 ) were not phosphorylated. A portion of fragments 123 and 23 became associated with the anti-p65/protein A-sepharose beads during the phosphorylation reaction, as detcrmined by Coomassie blue staining. However, only fragment 123 (both the bead-associated and soluble populations) was phosphorylated, suggesting that stable interaction with the anti-p 65 beads was neither necessary nor sufficient for phosphorylation. Tryptic phosphopeptide mapping by reverse-phase HPLC of both in vitro phosphorylated $\mathrm{p} 65$ and fragment 123 yielded a single coeluting radioactive peak (Fig. $2 C$ ), suggesting that an identical site is phosphorylated on each protein.

The fact that $\mathbf{p} 65$ fragment 123 is phosphorylated and fragment 23 is not suggests that the p65 phosphorylation site is located within cytoplasmic domain 1 (amino acids 96-130), immediately adjacent to the transmembrane domain. The amino acid sequence of domain 1 (Table 1) includes three threonine residues (at positions 112,125 , and 128 ) that are potential phosphorylation sites. To determine which of these sites is phosphorylated by the coprecipitatcd kinase, synthetic peptides corresponding to portions of domain 1 were tested as kinase substrates (Table 1). Peptide A, which includes only Thr-112, was not detectably phosphorylated, while peptide B, which includes Thr- 125 and Thr-128, was a good substrate. Replacement of Thr-125 with Ala (peptide C) resulted in a twofold increase in the phosphorylation rate (relative to peptide B), while replacement of Thr-128 with Ala (peptide D) resulted in a 15fold reduction in the phosphorylation rate. Peptides $\mathrm{B}$ and $\mathrm{C}$ also dramatically reduced the phosphorylation of $\mathrm{p} 65$ (by acting as competitive substrates) while peptides $A$ and $D$ had no effect on p65 phosphorylation (data not shown). These results demonstrate that Thr- 128 of rat $\mathrm{p} 65$ is the site phosphorylated by a copurifying protein kinase. This threonine residue is conserved among all mammalian p65 isoforms identified to date (Perin et al., 1990, 1991; Geppert et al., 1991; Tugal et al., 1991), as well as two forms of 665 from the marine ray Discopyge ommata (Wendland et al., 1991).

The domain phosphorylated on the other major phosphoprotein in the anti-p65 immunoprecipitate, syntaxin, was evaluated by methods similar to those described above for $\mathrm{p} 65$. Bacterially expressed fragments of syntaxin were assayed for their abilities to serve as substrates for the anti-p65 immunoprecipitated kinase. A fragment that included the amino-terminal 75 amino acids of syntaxin was phosphorylated, while a fragment that included amino acid 76 through the carboxylterminal was not (data not shown). Within the first 75 amino acids of syntaxin, one potential phosphorylation site, Ser-14, exhibited flanking sequences that were very similar to those surrounding Thr- 128 of $\mathrm{p} 65$, suggesting that Ser-14 may be the phosphorylation site on syntaxin.

\section{Identification of the copurifying protein kinase as casein kinase II}

The sequences surrounding Thr- 128 of $\mathrm{p} 65$ (and Ser-14 of syntaxin) match the consensus sequence for casein kinase II substrates [(S/T)XX(E/D); Pearson and Kemp, 1991]. Casein kinase II is a ubiquitous protein kinase present in both the cytoplasm and nucleus (for review, see Tauzon and Traugh, 1991). It is composed of 38-42 kDa catalytic subunits ( $\alpha$ and $\alpha^{\prime}$ ) and a 26 $\mathrm{kDa}$ regulatory subunit $(\beta)$, and phosphorylates a broad range of physiological substrates. A number of properties distinguish casein kinase II from other protein kinases including stimulation by polyanions and physiological salt concentrations, inhibition by low concentrations of heparin, and the ability to utilize GTP as a phosphate donor. The protein kinase that copurifies with p65 displays each of these catalytic properties (data not shown), suggesting that it may be casein kinase II. To investigate this possibility further, we tested the anti-p65 immunoprecipitates for the presence of casein kinase II by Western blotting. The immunoprecipitation of the kinase activity capable of phosphorylating p65, syntaxin, and exogenous fragment 123 was dependent on the detergent used for solubilization of the synaptic vesicle preparation (Fig. $3 A$ ). Relatively low levels of kinase activity were recovered following CHAPS solubilization, intermediate levels following Triton X-100 solubilization, and high levels following octylglucoside solubilization. The differences in apparent kinase activity were not due to differential recoveries of p65 (Bennett et al., 1992a) or a p65 phosphatase activity, as assayed by the dephosphorylation of phosphopeptide 123 (data not shown). Western blot analysis of the immunoprecipitated samples revealed the presence of the catalytic subunits of casein kinase II (Fig. 3B). The amount of casein kinase II recovered in the immunoprecipitates correlated with the level of kinase activity as detected by in vitro phosphorylation, with lowest amounts recovered following CHAPS solubilization, intermediate amounts following Triton X-100 solubilization, and highest amounts $(12.5 \%$ of the total casein kinase II in the vesicle fraction) following octylglucoside solubilization. This result strongly supports the possibility that casein kinase II is respon- 
sible for the observed phosphorylation of p65. Casein kinase II is not an abundant protein in anti-p65 immunoprecipitates, as detected by Coomassie blue staining (see Fig. $1 \mathrm{~A}$ ), indicating that its copurification with p65 is not stoichiometric. However, the stoichiometric phosphorylation of p65 indicates that each casein kinase II molecule is capable of phosphorylating multiple p65 molecules.

The phosphorylation of p65 by a copurifying protein kinase has been noted previously (Petrenko et al., 1991). Although not studied in detail, this phosphorylation was found to occur on an unspecified threonine residue within the cytoplasmic domain of p65, consistent with the phosphorylation of Thr-128 that we have documented. The protein kinase responsible for the phosphorylation of p65 observed by Petrenko et al. (1991) utilized GTP as a phosphate donor, again consistent with our finding that casein kinase II phosphorylates p65. One apparent difference between our findings is the calcium sensitivity of p65 phosphorylation. Petrenko et al. (1991) reported that p65 phosphorylation is stimulated by calcium, while we found it to be independent of calcium (data not shown), as is the activity of casein kinase II (Tauzon and Traugh, 1991). The reason for this difference remains to be established.

The coimmunoprecipitation of casein kinase II with p65 raises the possibility that there may be a direct interaction between the two proteins. To investigate this possibility, fragments of the cytoplasmic domain of p65 [including fragments 123, 345, and IIs (amino acids 96-421); Fig. 2A] were prepared by expression in bacteria as GST fusion proteins, bound to glutathione-agarose beads, and used as ligands for affinity chromatography. A detergent-solubilized preparation of rat brain membranes was passed over the immobilized p65-containing columns and, after extensive washing, p65-binding proteins were eluted with $0.25 \mathrm{~m} \mathrm{NaCl}$. Western blot analysis of the column eluates (Fig. 4) demonstrated that casein kinase II bound specifically to p65 fragment 345 , but not to fragments 123 or IIs. Similar results were obtained using a rat brain cytosol fraction as the source of casein kinase II and by assaying for the presence of casein kinase II by phosphorylation of peptide $C$ (data not shown). The fact that fragment 345 bound casein kinase II while fragment IIs did not, even though the sequence of fragment 345 is entirely contained within fragment IIs, suggests that the putative casein kinase II binding site on fragment IIs is lost due to improper folding or blockage by the GST domain of the fusion protein. This possibility is supported by the observation that addition of bacterially expressed fragment 345 to a vesicle-enriched fraction greatly decreases the recovery of casein kinase II following detergent solubilization and immunoprecipitation with anti-p65 (data not shown). Since the fragment of p65 interacting with casein kinase II (345) is distinct from the fragment containing the phosphorylation site (123), the casein kinase IIp65 interaction does not simply represent an enzyme-substrate interaction.

The copurification of casein kinase II with substrate proteins has been observed previously. For example, immunoprecipitation of the tumor suppressor protein p53, which is phosphorylated by casein kinase II on Ser-389, results in the coprecipitation of casein kinase II (Meek et al., 1990). Casein kinase II also copurifies with clathrin-coated vesicles (Takahashi et al., 1985; Bar-Zvi and Branton, 1986), where it is associated with the $47 \mathrm{kDa}$ subunit of the HAI adaptor complex (Méresse et al., 1990). Among the in vitro substrates for casein kinase II in the clathrin-coated vesicle are the $\beta$-light chain of clathrin (Bar-

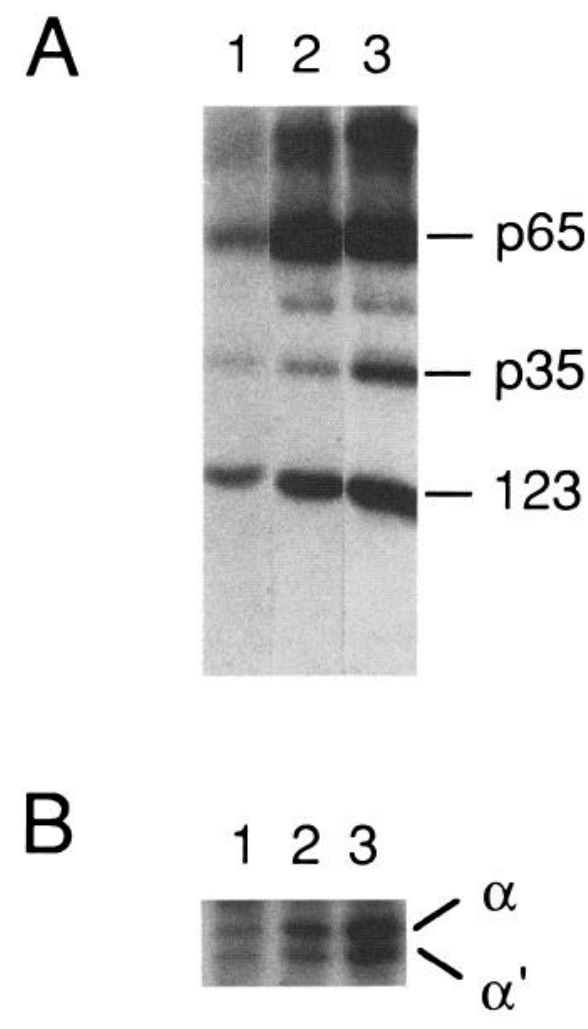

Figure 3. Coprecipitation of casein kinase II with anti-p65. In vitro phosphorylations $(A)$ and anti-casein kinase II Western blots $(B)$ of antip65 immunoprecipitates were performed as described in Materials and Methods. The synaptic vesicle-enriched fraction was solubilized in either CHAPS (lane 1), Triton X-100 (lane 2), or octylglucoside (lane 3) prior to immunoprecipitation. The phosphorylation reactions were performed in the presence of exogenous fragment 123. The positions of p65, syntaxin (p35), and fragment $123(A)$, and the $\alpha$ - and $\alpha^{\prime}$-subunits of casein kinase II $(B)$ are indicated. The $\beta$-subunit of casein kinase II was obscured by the light chain of anti-p65 and is not shown.

Zvi and Branton, 1986) and the cytoplasmic domain of the cation-independent mannose 6-phosphate receptor (Méresse et al., 1990). The interaction between a kinase and its substrate is one mechanism by which the activity of a broad substrate specificity kinase might be limited. Indeed, the type II regulatory subunit of cAMP-dependent protein kinase interacts with certain substrates and thereby localizes the catalytic subunit near a limited set of potential targets (Scott et al., 1990).

\section{Regulation of p65 phosphorylation by casein kinase II}

Although purified casein kinase II appears to be constitutively active, in vivo regulation of casein kinase II activity has been demonstrated. In cell culture, casein kinase II activity rapidly increases in response to insulin, insulin-like growth factor I, and epidermal growth factor (Sommercorn and Krebs, 1987; Klarlund and Czech, 1988; Ackerman and Osherhoff, 1989). Of particular interest with regard to the phosphorylation of p65 and syntaxin is a recent report demonstrating rapid activation of casein kinase II during long-term potentiation in hippocampal slices (Charriaut-Marlangue et al., 1991). Long-term potentiation, a form of synaptic plasticity thought to mimic the modulation of synaptic efficacy involved in the process of learning and memory, is likely to involve both pre- and postsynaptic mechanisms (Madison et al., 1991). The long-term potentiation-associated activation of a protein kinase capable of phos- 


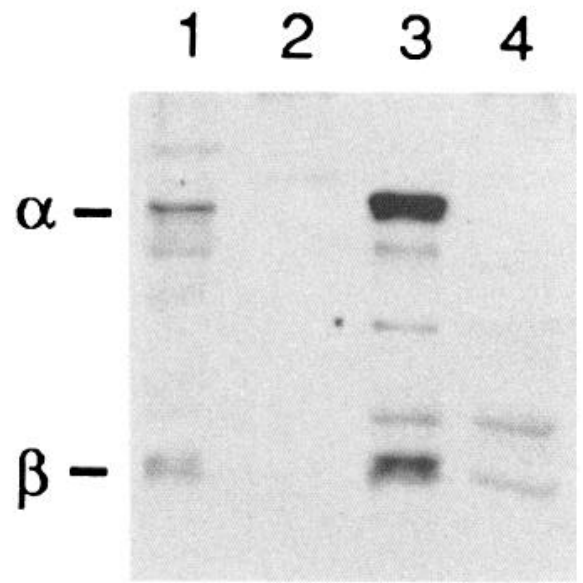

Figure 4. Interaction of casein kinase II with p65 fragments. A solubilized rat brain membrane preparation was passed over affinity columns containing immobilized p 65 fragments as described in Materials and Methods. The starting membrane fraction (lane 1) and the eluates from columns containing immobilized fragment 123 (lane 2), fragment 345 (lane 3), and fragment IIs (lane 4) were resolved by SDS-PAGE and analyzed by Western blotting with anti-casein kinase II antibody. The positions of the $\alpha$ - and $\beta$-subunits of casein kinase II are indicated.

phorylating two proteins (p65 and syntaxin) potentially involved in neurotransmitter release is an intriguing finding. Although the biochemical mechanism underlying the regulation of casein kinase II activity has not been established, a recent report has shown that sphingosine can stimulate purified casein kinase II in vitro (McDonald et al., 1991). Sphingosine, a basic structural component of sphingolipids, is a potent inhibitor of protein kinase C (Hannun et al., 1986) and may serve as a second messenger, generated from sphingolipid metabolism, capable of modulating a variety of cellular activities (Hannun and Bell, 1989).

To characterize further the in vitro phosphorylation of $\mathrm{p} 65$, we tested the effects of sphingosine, as well as other lipids and detergents, on p65 phosphorylation in a complex membrane preparation. A synaptic vesicle-enriched fraction, plus lipids or detergent, was incubated in the presence of $\gamma-{ }^{32} \mathrm{P}-\mathrm{ATP}$, and the phosphorylation patterns of the total sample (Fig. $5 \mathrm{~A}$ ) as well as anti-p65 immunoprecipitates (Fig. $5 B$ ) were compared. Relatively little phosphorylation of p65 was detected with no additions (lane 1). Upon addition of $30 \mu \mathrm{g} / \mathrm{ml}$ sphingosine (lane 2), p65 phosphorylation was stimulated without a dramatic effect on the total phosphorylation pattern. This suggests that the stimulation of casein kinase II by sphingosine observed with the purified enzyme (McDonald et al., 1991) can also occur in a complex membrane preparation. No stimulation of p65 phosphorylation was observed upon addition of $30 \mu \mathrm{g} / \mathrm{ml}$ ceramide, sphingomyelin, phosphatidylcholine, or octylglucoside (lanes 3 6 ), demonstrating that the sphingosine stimulation was lipid specific, and not a detergent effect. However, when the vesicle preparation was incubated with solubilizing concentrations of octylglucoside (1.6\%), a striking and specific increase in the phosphorylation of both p65 and syntaxin was observed (lane $7)$. Even though p65 and syntaxin represent only minor constituents of the vesicle preparation (as visualized by Coomassie blue staining), following octylglucoside solubilization they are among the dominant phosphoproteins. Other detergents, including CHAPS and Triton X-100, had the same effect as octylglucoside on p65 phosphorylation (data not shown; Petrenko et al., 1991). Detergent solubilization of the synaptic vesicleenriched fraction also resulted in increased phosphorylation of two exogenous substrates, fragment 123 and peptide $C$ (data not shown). This suggests that the observed increase in p65 phosphorylation may be due to stimulation of the kinase itself. The apparent detergent stimulation of casein kinase II could occur by several mechanisms, including (1) physical disruption of the native membrane structure, (2) removal or inactivation of an inhibitory compound or phosphatase, or (3) activation of or increased accessibility to a stimulatory compound. The mechanism and physiological relevance of the detergent stimulation of casein kinase II will be the topic of further experimentation.

We have demonstrated that p65 interacts with and is phosphorylated by casein kinase II. This phosphorylation, initially detected in anti-p65 immunoprecipitates, can occur in the native membrane environment in response to sphingosine and is strongly stimulated by detergent solubilization. We are now in a position to address the following important and interrelated questions regarding the phosphorylation of p65: (1) is p65 phosphorylated in vivo; (2) if so, how is this phosphorylation regu-
Figure 5. p65 phosphorylation in a synaptic vesicle preparation. A synaptic vesicle-enriched fraction was phosphorylated in vitro as described in Materials and Methods. One-tenth of each reaction was analyzed directly by SDS$\operatorname{PAGE}(A)$, while the remainder was immunoprecipitated with anti-p65 prior to SDS-PAGE analysis $(B)$. The phosphorylation reactions were performed with no additions (lane 1 ) or with the following additions: lane $2,30 \mu \mathrm{g} / \mathrm{ml}$ sphingosine; lane 3, $30 \mu \mathrm{g} / \mathrm{ml}$ ceramide; lane $4,30 \mu \mathrm{g} / \mathrm{ml}$ sphingomyelin; lane $5,30 \mu \mathrm{g} / \mathrm{ml}$ phosphatidylcholine; lane $6,30 \mu \mathrm{g} / \mathrm{ml}$ octylglucoside; and lane 7 , $1.6 \%$ octylglucoside. The positions of molecular weight standards, p65, and syntaxin (p35) are indicated.

\section{A B}

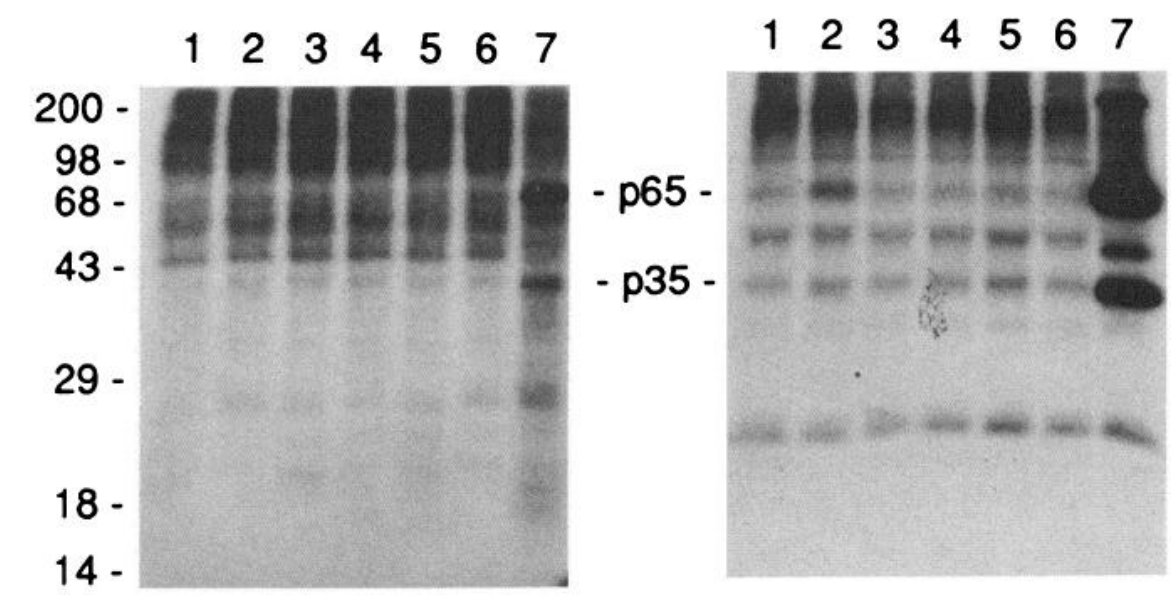


lated; and (3) what are the physiological consequences of p65 phosphorylation?

\section{References}

Ackerman P, Osherhoff N (1989) Regulation of casein kinase II activity by epidermal growth factor in human A-431 carcinoma cells. J Biol Chem 264:11958-11965.

Bar-Zvi D, Branton D (1986) Clathrin-coated vesicles contain two protein kinase activities. J Biol Chem 261:9614-9621.

Benfenati F, Valtorta F, Chieregatti E, Greengard P (1992) Interaction of free and synaptic vesicle-bound synapsin I with F-actin. Neuron $8: 377-386$

Bennett MK, Calakos N, Kreiner T, Scheller RH (1992a) Synaptic vesicle membrane proteins interact to form a multimeric complex. J Cell Biol 116:761-775.

Bennett MK, Calakos N, Scheller RH (1992b) Syntaxin: a synaptic protein implicated in docking of synaptic vesicles at presynaptic active zones. Science 257:255-259.

Brose N, Petrenko AG, Südhof TC, Jahn R (1992) Synaptotagmin: a calcium scnsor on the synaptic vesicle surface. Science 256:10211025 .

Charriaut-Marlangue C, Otani S, Creuzet C, Ben-Ari Y, Loeb J (1991) Rapid activation of hippocampal casein kinase II during long-term potentiation. Proc Natl Acad Sci USA 88:10232-10236.

Clark JD, Lin LL, Kriz RW, Ramesha CS, Sultzman LA, Lin AY, Milona N, Knopf JL (1991) A novel arachidonic acid-selective cytosolic PLA $\mathrm{PL}_{2}$ contains a $\mathrm{Ca}^{2+}$-dependent translocation domain with homology to PKC and GAP. Cell 65:1043-1051.

Dahmus GK, Glover CVC, Brutlag DL, Dahmus ME (1984) Similarities in structure and function of calf thymus and Drosophila casein kinase II. J Biol Chem 259:9001-9006.

DeCamilli P, Greengard P (1986) Synapsin I: a synaptic vesicle-associated neuronal phosphoprotein. Biochem Pharmacol 35:4349-4357.

Geppert M, Archer BT III, Südhof TC (1991) Synaptotagmin II. A novel differentially distributed form of synaptotagmin. J Biol Chem 266:13548-13552.

Guan KL, Dixon JE (1991) Eukaryotic proteins expressed in Escherichia coli: an improved thrombin cleavage and purification procedure of fusion proteins with glutathione S-transferase. Anal Biochem 192: 262-267.

Hanks SK, Quinn M (1991) Protein kinase catalytic domain sequence database: identification of conserved features of primary structure and classification of family members. Methods Enzymol 200:38-62.

Hannun YA, Bell RM (1989) Functions of sphingolipids and sphingolipid breakdown products in cellular regulation. Science 243:500507.

Hannun YA, Loomis CR, Merrill AH Jr, Bell RM (1986) Sphingosine inhibition of protein kinase $\mathrm{C}$ activity and of phorbol dibutyrate binding in vitro and in human platelets. J Biol Chem 261:1260412609 .

Huang FL, Huang K-P (1991) Interaction of protein kinase C isozymes with phosphatidylinositol 4,5-bisphosphate. J Biol Chem 266:87278733.

Huttner WB, Schiebler W, Greengard P, DeCamilli P (1983) Synapsin I (protein I), a nerve terminal-specific phosphoprotein. III. Its association with synaptic vesicles studied in a highly purified synaptic vesicle preparation. J Cell Biol 96:1374-1388.

Kelly RB (1988) The cell biology of the nerve terminal. Neuron 1:431438 .

Klarlund JK, Czech MP (1988) Insulin-like growth factor I and insulin rapidly increase casein kinase Il activity in BALB/c3T3 fibroblasts. J Biol Chem 263:15872-15875.

Laemmli UK (1970) Cleavage of structural proteins during the assembly of the head of bacteriophage T4. Nature 227:680-685.

Lee M-H, Bell RM (1991) Mechanism of protein kinase C activation by phosphatidylinositol 4,5-bisphosphate. Biochemistry 30:10411049.

Llinás R, McGuinness TL, Leonard CS, Sugimori M, Greengard P (1985) Intraterminal injection of synapsin I or calcium/calmodulindependent protcin kinasc II altcrs ncurotransmitter release at the squid giant synapse. Proc Natl Acad Sci USA 82:3035-3039.
Madison DV, Malenka RC, Nicoll RA (1991) Mechanisms underlying long-term potentiation of synaptic transmission. Annu Rev Neurosci 14:379-397.

Matthew WD, Tsavaler L, Reichardt LF (1981) Identification of a synaptic vesicle-specific membrane protein with a wide distribution in neuronal and neurosecretory tissue. J Cell Biol 91:257-269.

McDonald OB, Hannun YA, Reynolds CH, Sahyoun N (1991) Activation of casein kinase II by sphingosine. J Biol Chem 266:21773 21776.

Meek DW, Simon S, Kikkawa U, Eckhart W (1990) The p53 tumor suppressor protein is phosphorylated at serine 389 by casein kinase II. EMBO J 9:3253-3260.

Méresse S, Ludwig T, Frank R, Hoflack B (1990) Phosphorylation of the cytoplasmic domain of the bovine cation-independent mannose 6-phosphate receptor. J Biol Chem 265:18833-18842.

Pearson RB, Kemp BE (1991) Protein kinase phosphorylation site sequences and consensus specificity motifs: tabulations. Methods Enzymol 200:62-81.

Perin MS, Fried VA, Mignery GA, Jahn R, Südhof TC (1990) Phospholipid binding by a synaptic vesicle protein homologous to the regulatory region of protein kinase C. Nature 345:260-263.

Perin MS, Johnston PA, Özcelik T, Jahn R, Francke U, Südhof TC (1991) Structural and functional conservation of synaptotagmin (p65) in Drosophila and humans. J Biol Chem 266:615-622.

Petrenko AG, Perin MS, Davletov BA, Ushkaryov YA, Geppert M, Südhof TC (1991) Binding of synaptotagmin to the $\alpha$-latrotoxin receptor implicates both in synaptic vesicle exocytosis. Nature 353 : 65-68.

Racker E, Sen PC (1991) Assay of phosphorylation of small substrates and of synthetic random polymers that interact chemically with adenosine 5'-triphosphate. Methods Enzymol 200:112-114.

Schiebler W, Jahn R, Doucet J-P, Rothlein J, Greengard P (1986) Characterization of synapsin I binding to small synaptic vesicles. J Biol Chem 261:8383-8390.

Scott JD, Stofko RE, McDonald JR, Comer JD, Vitalis EA, Mangili JA (1990) Type II regulatory subunit dimerization determines the subcellular localization of the cAMP-dependent protein kinase. J Biol Chem 265:21561-21566.

Smith PK, Krohn RI, Hermanson GT, Mallia AK, Gartner FH, Provenzano MD, Fujimoto EK, Goeke NM, Olson BJ, Klenk DC (1985) Measurement of protein using bicinchoninic acid. Anal Biochem 150: 76-85.

Sommcrcorn J, Krebs EG (1987) Induction of casein kinase II during differentiation of 3T3-L1 cells. J Biol Chem 262:3839-3843.

Südhof TC, Jahn R (1991) Proteins of synaptic vesicles involved in exocytosis and membrane recycling. Neuron 6:665-677.

Südhof TC, Czernik AJ, Kao H-T, Takei K, Johnston PA, Horiuchi A Kanazir SD, Wagner MA, Perin MS, DeCamilli P, Greengard P (1989) Synapsins: mosaics of shared and individual domains in a family of synaptic vesicle phosphoproteins. Science 245:1474-1480.

Takahashi A, Usami M, Kadota T, Kadota K (1985) Properties of protein kinases in brain coated vesicles. J Biochem 98:63-68.

Tauzon PT, Traugh JA (1991) Casein kinase I and II-multipotential serine protein kinases: structure, function and regulation. Adv Second Messenger Phosphoprotein Res 23:123-164.

Towbin H, Staehelin T, Gordon J (1979) Electrophoretic transfer of proteins from polyacrylamide gels to nitrocellulose sheets: procedures and some applications. Proc Natl Acad Sci USA 76:4350-4354.

Trimble WS, Scheller RH (1988) Molecular biology of synaptic vesicle-associated proteins. Trends Neurosci 11:241-242.

Trimble WS, Linial M, Scheller RH (1991) Cellular and molecular biology of the presynaptic nerve terminal. Annu Rev Neurosci 14: 93-122.

Tugal HB, van Leeuwen F, Apps DK, Haywood J, Phillips JH (1991) Glycosylation and transmembrane topography of bovine chromaffin granule p65. Biochem J 279:699-703.

Wendland B, Miller KG, Schilling J, Scheller RH (1991) Differential expression of the p65 gene family. Neuron 6:993-1007. 